Portland State University

PDXScholar

6-16-2021

\title{
Bryophyte Ecosystem Services: How Bryophytes Impact Ecosystem Processes and Their Use in Urban Systems
}

Keila Spangler

Portland State University

Follow this and additional works at: https://pdxscholar.library.pdx.edu/honorstheses

Part of the Biology Commons, and the Bryology Commons Let us know how access to this document benefits you.

Recommended Citation

Spangler, Keila, "Bryophyte Ecosystem Services: How Bryophytes Impact Ecosystem Processes and Their Use in Urban Systems" (2021). University Honors Theses. Paper 1042.

https://doi.org/10.15760/honors.1068

This Thesis is brought to you for free and open access. It has been accepted for inclusion in University Honors Theses by an authorized administrator of PDXScholar. Please contact us if we can make this document more accessible: pdxscholar@pdx.edu. 
Bryophyte Ecosystem Services:

How Bryophytes Impact Ecosystem Processes and Their Use in Urban Systems

by

\section{Keila Spangler}

An undergraduate honors thesis submitted in partial fulfillment of the

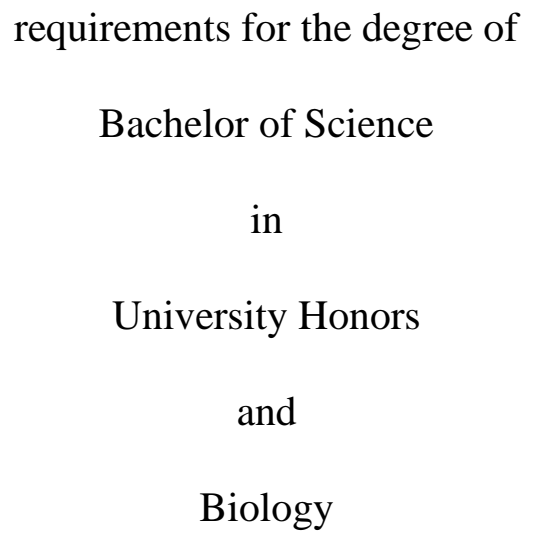

Thesis Adviser

Dr. Sarah Eppley

Portland State University 


\section{Introduction}

As climate change and urbanization effect biodiversity and change ecosystems, understanding the relationships among species and how these relationships will change is important in developing effective conservation efforts. One powerful tool to estimate the effects of climate change on biodiversity has been the use of empirical niche models to identify exposure to climate change (Schwartz 2012). However, because climate change and its effects on biodiversity is a complex issue, examining vulnerability, exposure, sensitivity, and adaptive capacity of a species or population is necessary to accurately predict losses and plan conservation methods (Dawson et al. 2011). Therefore, it is critical to research species' sensitivities, vulnerability, and ability to adapt in order to potentially mitigate the effects of climate change over the next century particularly for understudied groups.

Bryophytes, which include mosses, liverworts, and hornworts, are one understudied group of plants and expected to be negatively impacted by climate change and land use changes. Bryophytes are non-vascular plants (without roots or xylem to move water through their stems); they are poikilohydric (they have the inability to regulate water content independently of their environment); and they reproduce by spores rather than by seeds. However, research regarding the effects of climate change on plants and land use changes is heavily skewed towards vascular plants (e.g., flowering plants and conifers). Due to differences between bryophytes and vascular plants, such as size differences and the life strategy of bryophytes, studies on vascular plants cannot be used to predict the response of bryophytes to climate change (He et al. 2016, Turetsky 2003, Zanatta et al. 2020). Although many bryophytes are desiccation tolerant (the ability to withstand long periods of dryness), He et al. (2016) suggests that temperate species of bryophytes may only tolerate a $2-3^{\circ} \mathrm{C}$ increase in temperature before photosynthetic rates will be negatively impacted. Climate change is not the only threat to bryophytes though. Research 
suggests that bryophyte diversity will decrease in areas where development and habitat degradation occur (Gignac 2001, Pykälä 2019). Despite the gap in research compared to vascular plants, bryophytes represent the second largest group of green land plants after flowering plants with approximately 20,000 species (Patiño \& Vanderpoorten 2018) and a nearly global distribution (Gignac 2001, Pharo \& Zartman 2007).

Although bryophytes may be small and inconspicuous compared to many vascular species, that does not imply that they are less important than vascular plants in their communities. Many bryophyte species, such as Sphagnum species (Jassey et al. 2013), are ecosystem engineers (organisms that modify their environment to create habitat) which can help to maintain community biodiversity (Gavini et al. 2019). In addition, bryophyte provide important ecosystem services such as altering nutrient availability and cycling carbon and water (Turetsky 2003). Bryophytes can benefit humans directly as well. Bryophytes have been used as a garden substrate in countries like Japan and have been used by Indigenous peoples as medicine (Glime 2017, Martin 2015). Although more research is needed, bryophytes may be useful as green roof vegetation (Anderson et al. 2010, Glime 2017), as bioindicators (Govindapyari 2010, Koroleva 2020, Oishi \& Hiura 2017, Shi et al. 2017), in horticulture (Glime 2017. Martin 2015), and in modern medicine (Decker \& Reski 2020). Given that their future in the face of climate change remains unclear, conservation efforts will be needed to assure that bryophyte ecosystem services are not significantly reduced. Generating interest in bryophytes through their benefits to humans maybe be an effective conservation strategy. 


\section{Bryophyte Ecosystem Services in Natural Systems}

Bryophytes are considered ecosystem engineers that strongly influence ecosystem processes. In natural systems, these services include but are not limited to global nutrient and carbon cycling (Cornelissen et al. 2007, Crowley and Bedford 2011, Porada et al. 2013, Turetsky 2003), regulation of soil temperature (Gornall et al. 2007, Sun et al. 2017), water retention (Gignac 2001, Michel et al. 2013, Turetsky et al. 2012), and maintenance of community level biodiversity (Buchholz 2016, Cornelissen et al. 2007, Crowley and Bedford 2011, Gavini et al. 2019, Glime 2017). It is important to understand the extent to which bryophytes influence these processes and how losses to diversity and biomass of bryophytes could may cascading effects for communities. The following will explore the role of bryophytes in carbon cycling, water cycling, nutrient cycling, and community level biodiversity.

\subsection{Carbon Cycling}

Carbon cycling occurs as carbon from the atmosphere moves to reservoirs such as the ocean, organisms, soil, and rocks. Like vascular plants, bryophytes influence this cycle through their growth and metabolic processes such as photosynthesis and respiration (Turetky 2003). Net primary production (the rate at which biomass is stored; NPP) represents the difference between the carbon gained through photosynthesis and carbon lost through respiration; this difference can be used to determine the amount of carbon stored by plants (Bowman et al. 2017). A global estimate of NPP is an important parameter to determine because it quantifies the carbon cycle and storage of plants and informs predictions of the effects of climate change (Ito 2011). A study on three moss species' NPP in a subarctic system found that twenty-five percent of the system's carbon was stored by non-vascular plants (Campioli et al. 2008). While the NPP of vascular plants has been studied intensely (Gower et al. 2001, Potter et al. 2012, Xing et al. 2010), 
research on the NPP of bryophytes and how climate change will impact their role in carbon cycling remains understudied particularly for tropical species.

Peatland, terrestrial wetland ecosystems that are often dominated by mosses, serve as important carbon sinks that hold at least 20 percent of stored carbon in terrestrial systems despite representing approximately 2.84 percent of total terrestrial land $\left(4.23\right.$ million $\left.\mathrm{km}^{2}\right)$ (Bragazza et al. 2006, Heijmans et al. 2008, Xu et al. 2018). Many dominant mosses in cool peatlands are in the genus Sphagnum (also known as peat mosses), but understanding whether climate change will increase or decrease carbon storage in Sphagnum peatlands depends on a broad understanding of these complex systems. A model based on vegetation changes of peatlands in Demark and the UK by Heijmans et al. (2008) found that colonization by vascular plants as peat decomposition occurs may prevent these ecosystems from ultimately becoming carbon sources in the future. However, a meta-analysis by Hugelius et al. (2020) of over 7,000 field analyses of northern peatlands found that warmer climate and permafrost thawing may cause peatlands to have a net warming effect especially at their southern regions. Similarly, a review of 52 field experiments on the effects of warming, nitrogen addition, and vegetations composition change on greenhouse gas emissions from peatlands found highly variable results and suggests that multiple studies across a wide range of locations is needed to understand the response of peatlands to climate change (Gong et al. 2020).

Although the carbon storage of peatlands has been studied fairly intensely, the NPP of many tropical species of bryophytes remains largely unknown (Turetsky 2003). As stated above, photosynthetic rates of temperate species of bryophytes are hypothesized to suffer as global temperatures increase (He et al. 2016). Additionally, changes in precipitation patterns are expected to impact the carbon balance of tropical bryophytes as proper hydration is needed for 
growth and for preventing high respiration rates (Wagner et al. 2014). Much like peatlands in cold and temperate systems, tropical peatlands are important carbon sinks that are threatened by climate change and human activities such as land degradation (Hirano et al. 2012, Posa et al. 2011). Since the NPP for tropical bryophytes is not well researched, it is not possible to estimate the increase in $\mathrm{CO}_{2}$ emission from these species as the climate warms. Understanding how these species will react to climate change and how this will impact the global atmospheric carbon levels is key to mitigating the harmful effects of climate change.

\subsection{Water Cycling}

Due to their poikilohydric nature, bryophytes act as a temporary water storage space and alter water cycling within their community (Gignac 2001, Michel et al. 2013, Turetsky et al. 2012). For example, in semiarid climates, bryophytes significantly increase soil moisture content at shallow depths $(5 \mathrm{~cm})$ (Xiao et al. 2016). Bryophyte also regulate soil moisture through evaporation; Chen et al. (2019) found that soil water evaporation increased underneath mosses with increasing temperatures. These results suggest that mosses regulate soil temperature through evaporation similarly to how vascular plant regulate temperatures through transpiration.

However, bryophytes' greatest impact on water cycling is through rainfall interception. Porada et al. (2018) found that including lichens and bryophytes in a model of global rainfall interception increase total evaporation by 61 percent compared to a model that only included vascular plants.

Rainfall interception by bryophytes has been studied intensively in tropical montane cloud forests (high altitude tropical forests which experience regular cloud immersion). Epiphytic biomass of these forests, of which bryophytes can make up to seventy-five percent, play a key role in the uptake of water from cloud cover (Gotsch et al. 2016, Lakatos 2011). AhPeng et al. (2017) found that two liverwort species, Bazzania decrescens and Mastigophora 
diclados, stored the equivalent of $3.46 \mathrm{~mm}$ of rainwater through atmospheric water interception in a tropical montane cloud forest on the Mascarene Islands. Tropical montane cloud forests are expected to be negatively impacted by climate change as cloud cover moves upward and their range contracts. If cloud cover moves to locations where these communities cannot disperse to or to areas without suitable habitat, it is likely that losses to biodiversity will occur (Foster 2001). Due to their importance in capturing and storing atmospheric water, losses to bryophytes diversity and biomass could alter community level water cycling and have cascading effects on community structure in these forests. Research into how bryophytes alter the water cycling in montane cloud forests and other communities is critical to understanding their current importance in these systems as well as how their potential loss due to climate change may affect cycling in these systems.

\subsection{Nutrient Cycling}

In order for an ecosystem to function properly, nutrients need to be available for plants and other organisms to use. For example, nitrogen and phosphorus must be made avaible through fixation (de Bruijn 2015, Herridge et al. 2008) or mineralization (Bünemann 2015, Spohn \& Kuzyakov 2013). However, bryophytes also have a critical role in the nutrient cycling of communities. Bryophytes are ecosystem engineers that modify abiotic and biotic factors such as soil $\mathrm{pH}$, rocky substrate, and microbe biomass which can alter nutrient availability (Palozzi \& Lindo 2017, Turetsky et al. 2012) A study by Crowley and Bedford (2011) found that mosses in rich fens increased phosphorus availability for other plants through redox reaction which oxidize soils and resulted in greater arbuscular mycorrhizal fungi activity. The increase in phosphorus led to more growth of vascular species suggesting that the presences of mosses increase biodiversity in rich fens through nutrient cycling. Bryophytes can also cycle phosphorus without utilizing symbionts. 
Unlike most other land plants, bryophytes lack true roots and can grow on rocky surfaces. It is hypothesized that bryophytes living on rocks and in soils release weathering agents that make phosphorus available for their communities (Porada et al. 2014, Porada et al. 2016, Seppelt et al. 2016). Porada et al. (2014) estimates that bryophytes and lichens process 0.46 to $4.6 \mathrm{Tg}$ of phosphorous and weather 0.06 to $1.1 \mathrm{~km}^{3}$ of rock per year.

Bryophytes are also important for global nitrogen fixation and fix nitrogen through multiple pathways. Two significant forms of fixation by bryophytes occur through atmospheric deposition and biological fixation (symbiosis with cyanobacteria) (Lindo \& Whiteley 2011, Markham \& Fernández Otárola 2021, Turetsky 2003). In artic systems, mosses influence microorganisms that fix nitrogen by regulating soil temperature and moisture (Gornall et al. 2007). Similarly, Sun et al. (2017) found that the removal of bryophytes from the understory of shrubland and coniferous habitats decreased the biomass of the microbial community. Decreases in nitrogen fixing microbes could lead to lower plant growth and higher stress if the decrease is significant enough. Although a global estimation for the amount of nitrogen made available by bryophytes is not known, the nitrogen requirements (requirement and fixation estimates are usually similar) of lichens and bryophytes is estimated to be 3.5 to $34 \mathrm{Tg}$ per year (Porada et al. 2014). Similarly, a study by Elbert et al. (2012) estimated the global nitrogen fixation of cryptogams (plants that reproduce by spores) and their symbiotic cyanobacteria to be $49 \mathrm{Tg}$ per year. These studies suggest that bryophytes are important for global nitrogen fixation, and suggest that fixation rates are increased in ecosystems where demand for nitrogen is higher, such as deserts. 


\subsection{Community Biodiversity}

In order to have a healthy ecosystem, a diverse range of organisms are needed to provide critical ecosystem services (Ranius et al. 2018, Thom \& Seidl 2016). Biodiversity, is a measurement of the diversity of biological organisms in a system; it can measure genetic diversity within and among species across a range of scales including communities, ecosystems, or even globally (Bowman et al. 2017). In recent years, global losses to biodiversity cannot be understated; current extinction rates range from 1000 to 10,000 times higher than historic rates derived from fossil records (Barnosky et al. 2011, Singh 2002). Although extinction is a normal process, the rate at which is currently occurring is hypothesized to have negative cascading effects such as the collapse of seed dispersal (Butt et al. 2015, Pérez-Méndez et al. 2016), breakdown of plantpollinator relationships (Pires et al. 2020, and trophic collapse (Dobson et al. 2006). With losses to biodiversity at an all-time high, research should focus not just on how to conserve individual populations and species but on how to conserve the habitats in which threatened species occur. Bryophytes serve as a habitat for a variety of organisms. Micro and macroinvertebrates such as nematodes, rotifers, and Chironomidae are commonly found in bryophytes ranging from species that are exclusively found on bryophytes to those that associate with but do not required bryophytes to survive (Glime 2017). Additionally, symbionts such as cyanobacteria (Adams \& Duggan 2008, Lindo et al. 2013) and arbuscular mycorrhizal fungi (Rimington et al. 2018, Zhang \& Guo 2007) associate with bryophytes and increase nutrient availability. Birds also interact significantly with bryophytes (Chmielewski \& Eppley 2019); birds rely on bryophytes as a preferred or emergency food source, a place for foraging on invertebrates, and as a nesting material (Glime 2017). 
Bryophytes can also alter the communities in which they grow. A study by Rehm et al. (2019) on reforestation in Hawaii concluded that bryophytes were the most important substrate for seedling recruitment of 'ōhi'a (Metrosideros polymorpha) and koa (Acacia koa) trees. This study found that the mean seedling abundance was ten times higher for bryophytes than the second best substate, woody leaf litter, and that in koa corridors only bryophytes supported seedlings. Soil temperature regulation by bryophytes may also keep communities with healthy levels of plant, microbe (Gornall et al. 2007), and macroinvertebrate biodiversity (Neven 2000). Warming soil temperatures have been found to decrease plant and invertebrate diversity (Robinson et al. 2018) and negatively impact the efficiency of soil microbe communities (Frey et al. 2013, Sun et al. 2017). As soil microorganisms can increase nutrient and water availability for plants (Jeffries, et al. 2013), losses to bryophyte diversity and subsequent changes to soil microorganism communities may have a larger impact to communities than currently hypothesized.

Additionally, bryophytes also alter communities through allelopathy. Allelopathy is a defense mechanism found in some plant species where secondary metabolites produced by the plant negatively impact the growth of nearby organisms (Meiners et al. 2012). Allelopathy has been observed in Sphagnum species (Liu et al. 2020), and allelopathic compounds have been identified in the moss species, Rhynchostegium pallidifolium (Kato-Noguchi et al. 2010). In forest ecosystems of New Zealand, allelopathic activity of bryophytes negatively impact tree seedlings and their growth (Michel et al. 2011). Although allelopathic activity may seem to only have negative impacts, it also has a crucial role in maintaining biodiversity by influencing plant succession, dominance, and invasion (Chou 1999, Koocheki 2013). Additionally, secondary metabolites of bryophytes that have allelopathic activity may be an alternative source of 
pesticides and herbicides (Jabran et al. 2015, Latif et al. 2017, Zaynab et al. 2018). Although there is some research on the interactions with vascular plants, little research has looked at allelopathic interactions between bryophytes and non-vascular plants (Whitehead et al. 2018). In order to better understand the role of bryophytes in community biodiversity, it is important to research how their secondary metabolites are affecting the species growing around them.

Because bryophytes have such strong effects on biodiversity and community structure, future losses of bryophyte due to climate change will have large effects at the community level and these effects are already being seen in some moss communities. A good example would be the decomposition of peatlands. The range of peatland has been reduced significantly in the past century due to human activities, such as extraction, and are currently faced with the threat of climate change (Buchholz 2016, Gallé et al. 2019, Roucoux et al. 2017, Saarimaa et al. 2019). Peatlands provide habitat for many types of organisms, particularly in the order Odonata (dragonflies and damselflies) (Glimes 2017), and they contain a number of rare and specialist species, especially spiders. A study of spider assemblages in northern Germany found that different successional stages of bogs contained different assembles of spider species and that habitat specialists were negatively correlated with succession (Buchholz 2016). Sperle \& Bruelheide (2021) surveyed bog species in the Black Forest of Germany from 1972 to 1980 and from 2017 to 2020 . Of a total of 88 species, 37 decline during the study period and 2 went extinct; the authors concluded that higher temperatures and lower precipitation caused the decline since abundance declined the most at low elevations. These studies suggest, it is worth the effort to conserve some peatlands for specialist and rare species. Much of the research on peatland specialists has been on European bogs; however, research on tropical peatlands show that they contain unique plant assemblages and provide crucial habitat for at risk species (Posa et 
al. 2011, Yule 2010). Research should aim to identify specialists in tropical or other understudied bryophyte communities as they could be at extreme risk.

\section{Bryophyte Ecosystem Service in Urban Systems and Human Uses}

Urban areas have drastic impacts on ecosystems in the form of habitat fragmentation and degradation (Seto et al. 2011), increased pollution (Yuan et al. 2021), increased insecticide and herbicide use (Wittmer et al. 2011), and losses to biodiversity (Shochat et al. 2010). However, there has been a growing interest in sustainability and how lessen the effects of humans and our lifestyles on the environment (Kim \& Kwon 2018, Trencher et al. 2014). Bryophytes can play a role in efforts to make urban spaces and human needs more sustainable. On the one hand, bryophytes can be obstacles to a perfect lawn and roof, and unwanted bryophytes can be removed with herbicides and other means. However, these methods can have unwanted effects. For example, the cosmetic use of pesticides and herbicides is one of the main factors in the decline in insect abundance worldwide (Kawahara et al. 2021). Instead of removing bryophytes with environmentally damaging methods, there are beneficial ways to utilize them in urban spaces such as in green roofs, as bioindicators, and for humans benefits such as medicine and for horticulture.

\subsection{Green Roofs}

The use of green roofs is one topic related to sustainability that has generated interest in urban areas. Green roofs can help mitigate the negative effects of urbanization in cities. Benefits of green roofs include stormwater retention with improved water quality (Razzaghmanesh et al. 2014; Rowe 2011), reduced urban heat island effect (Razzaghmanesh et al. 2016; Susca et al. 2011), and improved urban biodiversity for insects, birds, and other organisms (Colla et al. 2009; 
MacIvor \& Lundholm 2001). Bryophytes may serve as a useful substrate for green roofs alone or in combination with other plants as they can spontaneously colonize roofs, are primary colonizers, and are desiccation tolerant (Anderson et al. 2010). Another benefit of using bryophytes is that they do not require fertilizer and may need less maintenance than other types of green roof vegetation (Glime 2017, Martin 2015). A study by Heim et al. (2014) on green roofs in Nova Scotia, Canada found that planting moss alongside Festuca rubra, a grass species, resulted in the grass species having a higher growth rate. This suggests that mosses may help a greater diversity of plants grow on green roofs. Because bryophytes are desiccation tolerant, they may be a good substrate choice in regions that experience arid weather where traditional green roof vegetation may struggle to survive drought. However, not all bryophyte species are equally suited for use as green roof substrate. Most bryophytes grow as colonies and can be classified into seven categories of life-forms (turfs, cushions, dendroids, mats, wefts, fans, and pendants) which can correlate to properties such as desiccation tolerance, light requirement, and moisture content (Bates 1998, Mägdefrau 1982, Oishi 2009). Cruz de Carvalho et al. (2019) identified 43 potential moss species for green roof in the Mediterranean basin and concluded that different moss life forms, such as turf and cushion forms, were more suitable for dry climates than other forms. Since climate change will lead to desertification in many areas, bryophytes may be a good choice as green roof substrates for their ability to dry out and remain alive. Most likely, individuals installing a green roof will not be experts in identifying bryophyte species and lifeform may be an easier, more accessible way to determine if a bryophyte is well suited for their needs. Unfortunately, bryophyte life-form categories are not systematically assigned and their associated properties may not solely be a result of a species' life-from (Bates 1998). A more systematic categorization paired with quantitative data on the properties of different life-forms is 
needed before suggesting what bryophyte species should be used on green roofs. Additionally, more research is needed to determine what specific species or life-forms would be best across a wide range of locations.

\subsection{Bioindicators}

Pollution is a serious issue for human health especially in urban areas. Pollutants can cause multiple health issues ranging from respiratory problems to cancer. Although pollution can harm anyone, research suggests that a person's socioeconomic status and race may correlate to the amount of pollutants that they are exposed to throughout their life (Gray et al. 2013, Vrijheid et al. 2012). As many of the instruments used to measure air quality and pollutants are costly, data often have low geographic resolution, and bioindicators are a cheaper alternative which can provide mush needed geographic resolution to pinpoint pollution hotspots. Bryophytes, particularly epiphytic species, have been used as bioindicators to monitor heavy metals, atmospheric nitrogen deposition, and other pollutants (Govindapyari 2010, Koroleva 2020, Oishi \& Hiura 2017, Shi et al. 2017, Turetsky 2003). For example, a study by Donovan et al. (2016) used an epiphytic moss species to identify the source of cadmium pollution. Compared to traditional methods of measuring air quality, bryophytes may potentially be a cost-effective way to monitor pollutants. However, the age of the epiphytic bryophytes is often unknown which may cause issues for long term monitoring. Bryophytes on green roofs may be beneficial as bioindicators. Since the age of a green roof is known, bryophytes on green roofs could serve as bioindicators where time is a known and measurable variable. Further research is needed to determine wither this method would give comparable results to traditional instrumentation. If bryophytes on green roofs are reliable bioindicators, they would provide communities not only 
with air quality monitoring but also with the benefits of green roofs such as a reduction of the urban heat island effect.

\subsection{Horticulture}

Although bryophytes have historically been used in horticulture as a substrate, often in the form of peat, moss gardens are slowly becoming more popular. In 2015, Annie Martin, also known as Mossin’ Annie, published her book The Magical World of Moss Gardening which details the history of moss gardens, the basics of bryophyte biology, descriptions of species useful for gardeners, and how to take care of and maintain a moss garden. Moss gardens are particularly popular in Japan where they have a long history, however moss gardens can also be found in the UK, the US, Canada and elsewhere (Glime 2017, Martin 2015). Compared to traditional lawns, moss gardens offer unique benefits. For example, moss gardens do not require fertilizer (addition may be detrimental); they provide habitat for beneficial insect, salamanders, and other organism that traditional lawns do not support; the need for herbicides and pesticides is lower due to naturally occurring secondary metabolites; water usage is decrease compared to lawns; and machine powered garden tools are not needed (Martin 2015, Glime 2017). However, care needs to be taken as moss gardens gain popularity. Overharvesting is a serious conservation issue and usually occurs when there is a growing demand for a product. For example, many rare succulents and other popular houseplants are threatened by overharvesting (Liu et al. 2018, Victor \& Makwarela 2011). Overharvesting of bryophytes is not just a potential issue with horticulture; mosses for green roofs and other uses also need to be harvested in a sustainable way.

\subsection{Uses by Indigenous Peoples}

In 2003, Robin Wall Kimmerer, a professor at the State University of New York College of Environmental Science and Forestry and a member of the Potawatomi Nation, published 
Gathering Moss: A Natural and Cultural History of Mosses. Her book explores mosses through personal essays with topics ranging from ecological succession to urban areas. In her chapter entitled "The Web of Reciprocity: Indigenous Uses of Moss," Kimmerer details how mosses have been used by indigenous peoples of North America in a variety of ways including diapers, sanitary napkins, insulation, and food preparation (Kimmerer 2003). Janice Glime also reviews the potential medicinal uses of bryophytes in her book Bryophyte Ecology. Bryophytes have been used in herbal medicines in China, India, North America, and elsewhere to treat various health issues such as liver disease, fungal infections, cardiovascular disease, inflammation, and lung disease (Glime 2017). For example, Polytrichum species were traditionally used by indigenous women of North America to assist with childbirth (Martin 2015, Glime 2017). In Chinese herbal medicine, Polytrichum commune has been used to treat symptoms of menopause and isolated secondary compounds from this species have shown anti-neuroinflammatory activity in vitro (Glime 2017, Guo et al. 2020). Compounds isolated from bryophytes may have a huge potential for modern medicine and their use in traditional medicine may be a great place to start investigating.

\subsection{In Modern Medicine}

As some of the first land plants, bryophytes have evolved to produce a vast number of secondary compounds. For example, liverwort species have been found to contain over 1600 terpenoids (a class of organic chemicals some of which exhibit bioactivity) (Chen et al. 2018). Similar to the research on Polytrichum commune by Guo et al. (2020), bryophytes have recently generated interest in pharmaceutical and biotechnology industries. In 2017, an enzyme replacement therapy drug for treating Morbus Fabry, a genetic disease. was made from Physcomitrella patens, a moss species, and has completed the first stage of its clinical trial (Decker \& Reski 2020). Although 
much of the research in phytochemistry (the study of plant produced chemicals), is focused on vascular plants, bryophytes contain many biologically active compounds, some unique to bryophytes, including lipids, proteins, terpenoids, and aromatic compounds (Commisso et al. 2021, Ludwiczuk \& Asakawa 2020).

Although the activity of many of these compounds is unknown, recent studies have demonstrated that they may be useful for human health and medicine. For example, bryophytes have also shown antiproliferative (cell growth suppressing) activity; a study by Vollár et al. (2018) of 168 extracts isolated from bryophytes found that extracts from the families Brachytheciaceae and Amblystegiaceae had the most antiproliferative activity for gynecological cancer cells. A review of liverwort and moss species' secondary metabolites by Ludwiczuk \& Asakawa (2019) found that activities of isolated compounds included phytotoxicity (toxic to plant grow), insect antifeedant, molluscicidal (poisonous to mollusks) activity, piscicidal (poisonous to fish) activity, antifungal activity, antimicrobial, cytotoxicity (toxic to cells), antiinflammatory, and more. Although not enough research has been done about the activities of these compounds, they may have great potential for medicine in the future.

\section{Bryophyte Conservation}

Bryophytes play a critical role in ecosystem services and have a wide range of use for humans indicating that conservation may be crucial for some species if they are threatened and endangered. Bryophyte diversity, range, biomass, and photosynthetic rates are expected to be negatively impacted by global warming (Gignac 2001, He et al. 2016, Turetsky 2003), and therefore research and development is needed into effective conservation strategies. As Dawson et al. (2011) suggests, it is not enough to only identity exposure to climate change as there is also a need to research species' sensitivities, vulnerability, and ability to adapt. In addition, 
investigations are critical into how humans are impacting bryophytes through means other than climate change such as habitat fragmentation and degradation, overharvesting, and the introduction of invasive species and diseases. Unlike vascular plants, bryophytes reproduce by spores rather than seeds which allows for greater dispersal ability (Gignac 2001, Patiño \& Vanderpoorten 2018). This ability may help bryophytes negate the harm of climate change as they will be able to move to suitable habitat with more ease compared to seed plants.

However, there is debate on whether bryophyte dispersal ability will be able to keep up with suitable habitat loss. Zanatta et al. (2020) argues that although the dispersal ability of bryophytes is quite good, simulations of climate and wind conditions over approximately the next 30 years suggest that even highly dispersive species will struggle to match the rate of range contractions due to climate change. Urban development may also negatively impact the range of suitable habitats available for species as their current habitats are degraded. Range contractions are not the only threat to bryophytes. Increased temperatures are hypothesized to negatively affect photosynthetic rates of bryophytes specifically for species adapted to specific habitats such as tropical montane cloud forests, alpine areas, and temperate regions (He et al. 2016).

Predicting how threatened, if at all, many bryophyte species are by climate change is difficult as data are lacking for many species. The International Union for Conservation of Nature (IUNC) lists 23 species as near threatened, 37 as vulnerable, 39 as endangered, 25 as critically endangered, 4 as extinct, and 18 as data deficient of 182 total species. Considering that current estimate of bryophytes species globally is around 20,000 species (Patiño \& Vanderpoorten 2018), data are certainly on many species. With extinction rates at an all-time high, research efforts may not be able to keep up and species may go extinct before they are even classified as at risk or even named (Howard \& Bickford 2014, Lees \& Pimm 2015). In addition 
to the large number of species without data, the current IUCN red list criteria are not easily applied to colonial and asexually reproducing organisms such as bryophytes, and Bergamini et al. (2019) suggests that definitions of generation length, mature individual, and fragmentation may need to be modified for bryophyte conservation. However, this does not suggest the IUCN red list for bryophytes is not useful. Similar to suggestions made by Bergamini et al. (2019), a study on the status of bryophyte species in the Canary Islands used modified IUCN criteria and found that 105out of 501 species were either critically endangered (7), endangered (20), or vulnerable (78) (González-Mancebo er al. 2012). Identifying all bryophyte species and evaluating their risk will not be possible in one go. Given the number of species with insufficient data and the nearly global range of bryophyte, efforts to document local species or species in particularly damaged habitats may be more effective. Once data on a status of a species is sufficient, assessing its sensitivities, vulnerability, and ability to adapt to climate change will be easier.

However, research on how bryophytes will respond to upcoming challenges will not be enough for effective conservation. An interdisciplinary approach that combines scientific, local, and indigenous knowledge is necessary for effective conservation as policies that are not livable are more likely to be ignored (Bartel 2014, Heller \& Zavaleta 2009, Reyes-García \& Benyei 2019). While traditional conservation approaches such as nature reserves and protected lands have been successful, they are not enough to combat the impacts of climate change (Corrigan et al. 2018, Reside et al. 2018) and can have negative social impacts, such as the removal of indigenous peoples from their home (Moola \& Roth 2018). Although not traditionally included, indigenous voices are important for conservation as they help avoid knowledge gaps such as culturally important species, unique ecosystems services, and data deficient species (Fernández- 
Llamazares et al. 2021, Reyes-García \& Benyei 2019). For example, bryophytes have been historically used in indigenous medicines but are just now being used in modern medicine (Glime 2017, Kimmerer 2003, Martin 2015). A study by Schuster et al. (2019) on indigenousmanaged lands found equal or greater vertebrate biodiversity compared to nature reserves in Australia, Brazil and Canada. Similarly, Inuit management practices have positively impacted local biodiversity, created unique plant assemblages, and increased soil nutrients (Oberndorfer et al. 2020). Climate change and urbanization will undeniably make conservation efforts more difficult than they already are. An interdisciplinary effort including local and indigenous voices will be crucial to conservation efforts in the coming years.

\section{Conclusion}

Bryophytes have a broad range of uses for humans and provide important ecosystem services that keep communities healthy. As interest in a more sustainable future grows, bryophytes may help humans have a more sustainable life style particularly in urban areas. When used a substrate for green roofs, bryophyte will help reduce problem such as the urban heat island effect while simultaneously being a better substate choice in areas that experience times of arid weather due to their desiccation tolerance. In urban areas experiencing high levels of pollution, bryophyte can be used a bioindicators. Not only will this be a cheaper alternative to traditional air quality monitoring methods, combining bryophytes with green roofs may be more effective at monitoring pollution long term compared to just using epiphytic bryophytes. For individuals in the right climate, mosses may be a good alternative to a traditional lawn as they provide habitat for local fauna while decreasing the need for harmful upkeep like the use of pesticides. Although they have long been used by indigenous peoples as traditional medicines, interest in the use bryophytes' secondary compounds in modern medicine is just beginning. Isolated compounds 
from bryophytes have been found to have activities including antifungal, antimicrobial, cytotoxicity, and anti-inflammatory properties. Although there are many possible research paths, researching focusing on green roofs and medicine would most likely benefit the greatest amount of people. Green roofs benefit communities by alleviating some negative aspects of urbanization while also creating much needed habitat for urban insects and other organisms. For moss green roofs to be successful, research needs to be done to determine what climates support mosses and what species are best suited as green roof substate. Similarly, research is needed to not only identify the broad range of secondary compounds of bryophytes but also to determine what biological activity they express. Given the large number of bryophyte species, it may necessary to continue to examine how bryophytes were used in traditional medicines in order to identify potentially helpful species.

However, for all of the positive possibilities of bryophytes for human use, there remains the possibility that climate change and habitat degradation will cause significant losses to bryophyte biodiversity. Considering the important ecosystem services bryophytes provide such a carbon, water, and nutrient cycling as well as maintaining community biodiversity, a reduction in bryophyte biodiversity may have cascading effects. The most noticeable effect of climate change on bryophytes may be increase in greenhouse gas emissions from peatlands. As these systems hold at least 20 percent of terrestrial carbon, the decomposition of peatlands could significantly increase the amount of carbon dioxide in the atmosphere. However, there are numerous species of bryophytes whose risk levels have yet to be evaluated. Although it may be the case that the high dispersal ability of many bryophyte species will be able to keep up with range contractions due to climate change, it remains understudied. Before assuming bryophytes will be able to withstand climate change, researchers need to define and implement criteria on how to classify 
the risk status of bryophyte species. In addition to whether a species is at risk currently, research is needed to assess how bryophytes will respond as the effects of climate change worsen particularly for data deficient species. As more research is focused on bryophytes and people are induced to bryophytes' benefits, interest may increase in their conservation and their use in sustainable urban environments. 


\section{References}

Adams, D. G., \& Duggan, P. S. (2008). Cyanobacteria-bryophyte symbioses. Journal of Experimental Botany, 59(5), 1047-1058. https://doi.org/10.1093/jxb/ern005

Ah-Peng, C., Cardoso, A. W., Flores, O., West, A., Wilding, N., Strasberg, D., \& Hedderson, T. A. J. (2017). The role of epiphytic bryophytes in interception, storage, and the regulated release of atmospheric moisture in a tropical montane cloud forest. Journal of Hydrology, 548, 665-673. https://doi.org/10.1016/j.jhydrol.2017.03.043

Alvarenga, L. D. P. \& Pôrto, K. C. (2007). Patch size and isolation effects on epiphytic and epiphyllous bryophytes in the fragmented Brazilian Atlantic forest. Biological Conservation, 134(3), 415-427. https://doi.org/10.1016/j.biocon.2006.08.031

Anderson, M., Lambrinos, J., \& Schroll, E. (2010). The potential value of mosses for stormwater management in urban environments. Urban Ecosystems, 13(3), 319-332. https://doi.org/10.1007/s11252-010-0121-z

Araújo, M. B., \& Rahbek, C. (2006). How does climate change affect biodiversity? Science, 313(5792), 1396-1397. https://doi.org/10.1126/science.1131758

Barnosky, A. D., Matzke, N., Tomiya, S., Wogan, G. O. U., Swartz, B., Quental, T. B., Marshall, C., McGuire, J. L., Lindsey, E. L., Maguire, K. C., Mersey, B., \& Ferrer, E. A. (2011). Has the Earth's sixth mass extinction already arrived? Nature, 471(7336), 51-57. https://doi.org/10.1038/nature09678

Bartel, R. (2014). Vernacular knowledge and environmental law: Cause and cure for regulatory failure. Local Environment, 19(8), 891-914. https://doi.org/10.1080/13549839.2013.798636 
Bates, J. W. (1998). Is "life-form" a useful concept in bryophyte ecology? Oikos, 82(2), 223237. https://doi.org/10.2307/3546962

Bergamini, A., Bisang, I., Hodgetts, N., Lockhart, N., Rooy, J. van, \& Hallingbäck, T. (2019). Recommendations for the use of critical terms when applying IUCN red-listing criteria to bryophytes. Lindbergia, 2019(1), 1-6. https://doi.org/10.25227/linbg.01117

Boch, S., Allan, E., Humbert, J.Y., Kurtogullari, Y., Lessard-Therrien, M., Müller, J., Prati, D., Rieder, N. S., Arlettaz, R., \& Fischer, M. (2018). Direct and indirect effects of land use on bryophytes in grasslands. Science of The Total Environment, 644, 60-67. https://doi.org/10.1016/j.scitotenv.2018.06.323

Bowman, W.D., Hacker, S.D., Cain M.L.. (2017) Ecology. $4^{\text {th }}$ Edition. Sinauer Associates, Inc.

Bragazza, L., Freeman, C., Jones, T., Rydin, H., Limpens, J., Fenner, N., Ellis, T., Gerdol, R., Hájek, M., Hájek, T., lacumin, P., Kutnar, L., Tahvanainen, T., \& Toberman, H. (2006). Atmospheric nitrogen deposition promotes carbon loss from peat bogs. Proceedings of the National Academy of Sciences of the United States of America, 103(51), 1938619389.

Buchholz, S. (2016). Natural peat bog remnants promote distinct spider assemblages and habitat specific traits. Ecological Indicators, 60, 774-780. https://doi.org/10.1016/j.ecolind.2015.08.025

Bünemann, E. K. (2015). Assessment of gross and net mineralization rates of soil organic phosphorus - A review. Soil Biology and Biochemistry, 89, 82-98. https://doi.org/10.1016/j.soilbio.2015.06.026 
Butt, N., Seabrook, L., Maron, M., Law, B. S., Dawson, T. P., Syktus, J., \& McAlpine, C. A. (2015). Cascading effects of climate extremes on vertebrate fauna through changes to low-latitude tree flowering and fruiting phenology. Global Change Biology, 21(9), 32673277. https://doi.org/10.1111/gcb.12869

Campioli, M., Samson, R., Michelsen, A., Jonasson, S., Baxter, R., \& Lemeur, R. (2008). Nonvascular contribution to ecosystem NPP in a subarctic heath during early and late growing season. Plant Ecology, 202(1), 41. https://doi.org/10.1007/s11258-008-9527-6

Chen, F., Ludwiczuk, A., Wei, G., Chen, X., Crandall-Stotler, B., \& Bowman, J. L. (2018). Terpenoid secondary metabolites in bryophytes: Chemical diversity, biosynthesis and biological functions. Critical Reviews in Plant Sciences, 37(2-3), 210-231. https://doi.org/10.1080/07352689.2018.1482397

Chen, S., Yang, Z., Liu, X., Sun, J., Xu, C., Xiong, D., Lin, W., Li, Y., Guo, J., \& Yang, Y. (2019). Moss regulates soil evaporation leading to decoupling of soil and near-surface air temperatures. Journal of Soils and Sediments, 19(7), 2903-2912. http://dx.doi.org.proxy.lib.pdx.edu/10.1007/s11368-019-02297-4

Chmielewski, M. W., \& Eppley, S. M. (2019). Forest passerines as a novel dispersal vector of viable bryophyte propagules. Proceedings of the Royal Society. B, Biological Sciences, 286(1897), 20182253-20182253. https://doi.org/10.1098/rspb.2018.2253

Chou, C.-H. (1999). Roles of allelopathy in plant biodiversity and sustainable agriculture. Critical Reviews in Plant Sciences, 18(5), 609-636. https://doi.org/10.1080/07352689991309414 
Colla, S., Willis, E., \& Packer, L. (2009). Can green roofs provide habitat for urban bees (Hymenoptera: Apidae)? Cities and the Environment (CATE), 2(1).

Commisso, M., Guarino, F., Marchi, L., Muto, A., Piro, A., \& Degola, F. (2021). BryoActivities: A review on how bryophytes are contributing to the arsenal of natural bioactive compounds against fungi. Plants, 10(2), 203. https://doi.org/10.3390/plants10020203

Cornelissen, J. H. C., Lang, S. I., Soudzilovskaia, N. A. \& During, H. J. (2007). Comparative cryptogam ecology: A review of bryophyte and lichen traits that drive biogeochemistry. Annals of Botany, 99(5), 987-1001.

Corrigan, C., Bingham, H., Shi, Y., Lewis, E., Chauvenet, A., \& Kingston, N. (2018). Quantifying the contribution to biodiversity conservation of protected areas governed by indigenous peoples and local communities. Biological Conservation, 227. https://doi.org/10.1016/j.biocon.2018.09.007

Costa, D. P. D., \& Faria, C. P. D. (2008). Conservation priorities for the bryophytes of Rio de Janeiro State, Brazil. Journal of Bryology, 30(2), 133-142. https://doi.org/10.1179/174328208X300633

Crowley, K. F., \& Bedford, B. L. (2011). Mosses influence phosphorus cycling in rich fens by driving redox conditions in shallow soils. Oecologia, 167(1), 253-265. https://doi.org/10.1007/s00442-011-1970-8

Cruz de Carvalho, R., Varela, Z., do Paço, T. A., \& Branquinho, C. (2019). Selecting Potential Moss Species for Green Roofs in the Mediterranean Basin. Urban Science, 3(2), 57. https://doi.org/10.3390/urbansci3020057 
Dawson, T. P., Jackson, S. T., House, J. I., Prentice, I. C., \& Mace, G. M. (2011). Beyond predictions: Biodiversity conservation in a changing climate. Science, 332(6025), 53-58. de Bruijn, F. J. (2015). Biological nitrogen fixation. In B. Lugtenberg (Ed.), Principles of PlantMicrobe Interactions: Microbes for Sustainable Agriculture (pp. 215-224). Springer International Publishing. https://doi.org/10.1007/978-3-319-08575-3_23

Decker, E. L., \& Reski, R. (2020). Mosses in biotechnology. Current Opinion in Biotechnology, 61, 21-27. https://doi.org/10.1016/j.copbio.2019.09.021

Dobson, A., Lodge, D., Alder, J., Cumming, G. S., Keymer, J., McGlade, J., Mooney, H., Rusak, J. A., Sala, O., Wolters, V., Wall, D., Winfree, R., \& Xenopoulos, M. A. (2006). Habitat loss, trophic collapse, and the decline of ecosystem services. Ecology, 87(8), 1915-1924. https://doi.org/10.1890/0012-9658(2006)87[1915:HLTCAT]2.0.CO;2

Donovan, G. H., Jovan, S. E., Gatziolis, D., Burstyn, I., Michael, Y. L., Amacher, M. C., \& Monleon, V. J. (2016). Using an epiphytic moss to identify previously unknown sources of atmospheric cadmium pollution. Science of The Total Environment, 559, 84-93. https://doi.org/10.1016/j.scitotenv.2016.03.182

Elbert, W., Weber, B., Burrows, S., Steinkamp, J., Büdel, B., Andreae, M. O., \& Pöschl, U. (2012). Contribution of cryptogamic covers to the global cycles of carbon and nitrogen. Nature Geoscience, 5(7), 459-462. https://doi.org/10.1038/ngeo1486

Fernández-Llamazares, Á., López-Baucells, A., Velazco, P. M., Gyawali, A., Rocha, R., Terraube, J., \& Cabeza, M. (2021). The importance of Indigenous Territories for conserving bat diversity across the Amazon biome. Perspectives in Ecology and Conservation, 19(1), 10-20. https://doi.org/10.1016/j.pecon.2020.11.001 
Foster, P. (2001). The potential negative impacts of global climate change on tropical montane cloud forests. Earth-Science Reviews, 55(1), 73-106. https://doi.org/10.1016/S0012$\underline{8252(01) 00056-3}$

Frey, S. D., Lee, J., Melillo, J. M., \& Six, J. (2013). The temperature response of soil microbial efficiency and its feedback to climate. Nature Climate Change, 3(4), 395-398. https://doi.org/10.1038/nclimate1796

Gallé, R., Samu, F., Zsigmond, A.-R., Gallé-Szpisjak, N., \& Urák, I. (2019). Even the smallest habitat patch matters: On the fauna of peat bogs. Journal of Insect Conservation, 23(4), 699-705. https://doi.org/10.1007/s10841-019-00164-8

Gavini, S. S., Suárez, G. M., Ezcurra, C., \& Aizen, M. A. (2019). Facilitation of vascular plants by cushion mosses in high-Andean communities. Alpine Botany, 129(2), 137-148. https://doi.org/10.1007/s00035-019-00222-6

Gignac, L. D. (2001). Bryophytes as indicators of climate change. The Bryologist, 104(3), 410420.

Glime, J. M. (2017). Chapter 1: The fauna: A place to call home. In J. M. Glime (Ed.). Bryophyte ecology subchapters (Vol. 2, pp. 1-16). Houghton, MI: Janice M. Glime.

Glime, J. M. (2017). Chapter 2-1: Medical uses: Medical conditions. In J. M. Glime (Ed.). Bryophyte ecology subchapters (Vol. 5, pp. 1-46). Houghton, MI: Janice M. Glime.

Glime, J. M. (2017). Chapter 4-1: Invertebrate: Introduction. In J. M. Glime (Ed.). Bryophyte ecology subchapters (Vol. 2, pp. 1-22). Houghton, MI: Janice M. Glime.

Glime, J. M. (2017). Chapter 7-4: Arthropods: Spiders and peatlands. In J. M. Glime (Ed.). Bryophyte ecology subchapters (Vol. 2, pp. 1-32). Houghton, MI: Janice M. Glime. 
Glime, J. M. (2017). Chapter 7-4: Gardening: Moss garden development and maintenance. In J. M. Glime (Ed.). Bryophyte ecology subchapters (Vol. 5, pp. 1-22). Houghton, MI: Janice M. Glime.

Glime, J. M. (2017). Chapter 11-5: Aquatic insects: Hemimetabola - Odonata. In J. M. Glime (Ed.). Bryophyte ecology subchapters (Vol. 2, pp. 1-24). Houghton, MI: Janice M. Glime.

Glime, J. M. (2017). Chapter 16-2: Birds and bryophytic food sources. In J. M. Glime (Ed.). Bryophyte ecology subchapters (Vol. 2, pp. 1-32). Houghton, MI: Janice M. Glime

Gong, Y., Wu, J., Vogt, J., \& Ma, W. (2020). Greenhouse gas emissions from peatlands under manipulated warming, nitrogen addition, and vegetation composition change: A review and data synthesis. Environmental Reviews. https://doi.org/10.1139/er-2019-0064

González-Mancebo, J. M., Dirkse, G. M., Patiño, J., Romaguera, F., Werner, O., Ros, R. M., \& Martín, J. L. (2012). Applying the IUCN Red List criteria to small-sized plants on oceanic islands: Conservation implications for threatened bryophytes in the Canary Islands. Biodiversity and Conservation, 21(14), 3613-3636. https://doi.org/10.1007/s10531-012-0385-0

Gornall, J. L., Jónsdóttir, I. S., Woodin, S. J., \& Van der Wal, R. (2007). Arctic mosses govern below-ground environment and ecosystem processes. Oecologia, 153(4), 931-941. https://doi.org/10.1007/s00442-007-0785-0

Gotsch, S. G., Nadkarni, N., \& Amici, A. (2016). The functional roles of epiphytes and arboreal soils in tropical montane cloud forests. Journal of Tropical Ecology, 32(5), 455-468. https://doi.org/10.1017/S026646741600033X 
Govindapyari, H., Leleeka, M., Nivedita, M., \& Uniyal, P. L. (2010). Bryophytes: indicators and monitoring agents of pollution. NeBIO, 1(1), 35-41.

Gower, S. T., Krankina, O., Olson, R. J., Apps, M., Linder, S., \& Wang, C. (2001). Net primary production and carbon allocation patterns of boreal forest ecosystems. Ecological Applications, 11(5), 1395-1411. https://doi.org/10.1890/10510761(2001)011[1395:NPPACA]2.0.CO;2

Gray, S. C., Edwards, S. E., \& Miranda, M. L. (2013). Race, socioeconomic status, and air pollution exposure in North Carolina. Environmental Research, 126, 152-158. https://doi.org/10.1016/j.envres.2013.06.005

Guo, Z., Bi, G., Zhang, Y., Li, J., \& Meng, D. (2020). Rare benzonaphthoxanthenones from Chinese folk herbal medicine Polytrichum commune and their anti-neuroinflammatory activities in vitro. Bioorganic Chemistry, 102, 104087. https://doi.org/10.1016/j.bioorg.2020.104087

He, X., He, K. S., \& Hyvönen, J. (2016). Will bryophytes survive in a warming world? Perspectives in Plant Ecology, Evolution and Systematics, 19, 49-60. https://doi.org/10.1016/j.ppees.2016.02.005

Heijmans, M. M. P. D., Mauquoy, D., Geel, B. V., \& Berendse, F. (2008). Long-term effects of climate change on vegetation and carbon dynamics in peat bogs. Journal of Vegetation Science, 19(3), 307-320. https://doi.org/10.3170/2008-8-18368

Heim, A., Lundholm, J., \& Philip, L. (2014). The impact of mosses on the growth of neighbouring vascular plants, substrate temperature and evapotranspiration on an extensive green roof. Urban Ecosystems, 17(4), 1119-1133. 
Heller, N. E., \& Zavaleta, E. S. (2009). Biodiversity management in the face of climate change: A review of 22 years of recommendations. Biological Conservation, 142(1), 14-32. https://doi.org/10.1016/j.biocon.2008.10.006

Herridge, D. F., Peoples, M. B., \& Boddey, R. M. (2008). Global inputs of biological nitrogen fixation in agricultural systems. Plant and Soil, 311(1), 1-18. https://doi.org/10.1007/s11104-008-9668-3

Hirano, T., Segah, H., Kusin, K., Limin, S., Takahashi, H., \& Osaki, M. (2012). Effects of disturbances on the carbon balance of tropical peat swamp forests. Global Change Biology, 18(11), 3410-3422. https://doi.org/10.1111/j.1365-2486.2012.02793.x

Horvat, V., Heras, P., García-Mijangos, I., \& Biurrun, I. (2017). Intensive forest management affects bryophyte diversity in the western Pyrenean silver fir-beech forests. Biological Conservation, 215, 81-91. https://doi.org/10.1016/j.biocon.2017.09.007

Howard, S. D., \& Bickford, D. P. (2014). Amphibians over the edge: Silent extinction risk of Data Deficient species. Diversity and Distributions, 20(7), 837-846. https://doi.org/10.1111/ddi.12218

Hugelius, G., Loisel, J., Chadburn, S., Jackson, R. B., Jones, M., MacDonald, G., Marushchak, M., Olefeldt, D., Packalen, M., Siewert, M. B., Treat, C., Turetsky, M., Voigt, C., \& Yu, Z. (2020). Large stocks of peatland carbon and nitrogen are vulnerable to permafrost thaw. Proceedings of the National Academy of Sciences, 117(34), 20438-20446. https://doi.org/10.1073/pnas.1916387117 
International Union for Conservation of Nature and Natural Resources., World Conservation Monitoring Centre., Association for Biodiversity Information., \& International Union for Conservation of Nature and Natural Resources. (2021). Gland, Switzerland: International Union for Conservation of Nature and Natural Resources. https://www.iucnredlist.org/

Ito, A. (2011). A historical meta-analysis of global terrestrial net primary productivity: Are estimates converging? Global Change Biology, 17(10), 3161-3175. https://doi.org/10.1111/j.1365-2486.2011.02450.x

Jabran, K., Mahajan, G., Sardana, V., \& Chauhan, B. S. (2015). Allelopathy for weed control in agricultural systems. Crop Protection, 72, 57-65. https://doi.org/10.1016/j.cropro.2015.03.004

Jassey, V. E., Chiapusio, G., Binet, P., Buttler, A., Laggoun-Défarge, F., Delarue, F., Bernard, N., Mitchell, E. A., Toussaint, M.-L., Francez, A.-J., \& Gilbert, D. (2013). Above- and belowground linkages in Sphagnum peatland: Climate warming affects plant-microbial interactions. Global Change Biology, 19(3), 811-823. https://doi.org/10.1111/gcb.12075

Jeffries, P., Gianinazzi, S., Perotto, S., Turnau, K., \& Barea, J.-M. (2003). The contribution of arbuscular mycorrhizal fungi in sustainable maintenance of plant health and soil fertility. Biology and Fertility of Soils, 37(1), 1-16. https://doi.org/10.1007/s00374-002-0546-5

Kato-Noguchi, H., Seki, T., \& Shigemori, H. (2010). Allelopathy and allelopathic substance in the moss Rhynchostegium pallidifolium. Journal of Plant Physiology, 167(6), 468-471. https://doi.org/10.1016/j.jplph.2009.10.018 
Kawahara, A. Y., Reeves, L. E., Barber, J. R., \& Black, S. H. (2021). Opinion: Eight simple actions that individuals can take to save insects from global declines. Proceedings of the National Academy of Sciences, 118(2). https://doi.org/10.1073/pnas.2002547117

Kim, S., \& Kwon, H. (2018). Urban sustainability through public architecture. Sustainability, 10(4), 1249. https://doi.org/10.3390/su10041249

Kimmerer, R. W. (2003). Gathering moss: A natural and cultural history of mosses. Oregon State University Press.

Koocheki, A., Lalegani, B., \& Hosseini, S. A. (2013). Ecological consequences of allelopathy. In Z. A. Cheema, M. Farooq, \& A. Wahid (Eds.), Allelopathy: Current Trends and Future Applications (pp. 23-38). Springer. https://doi.org/10.1007/978-3-642-30595-5_2

Koroleva, Y., Napreenko, M., Baymuratov, R., \& Schefer, R. (2020). Bryophytes as a bioindicator for atmospheric deposition in different coastal habitats (a case study in the Russian sector of the Curonian Spit, South-Eastern Baltic). International Journal of Environmental Studies, 77(1), 152-162. https://doi.org/10.1080/00207233.2019.1594301

Lakatos, M. (2011). Lichens and bryophytes: Habitats and species. In U. Lüttge, E. Beck, \& D. Bartels (Eds.), Plant Desiccation Tolerance (pp. 65-87). Springer. https://doi.org/10.1007/978-3-642-19106-0_5

Latif, S., Chiapusio, G., \& Weston, L. A. (2017). Chapter two-Allelopathy and the role of allelochemicals in plant defence. In G. Becard (Ed.), Advances in Botanical Research (Vol. 82, pp. 19-54). Academic Press. https://doi.org/10.1016/bs.abr.2016.12.001

Lees, A. C., \& Pimm, S. L. (2015). Species, extinct before we know them? Current Biology, 25(5), R177-R180. https://doi.org/10.1016/j.cub.2014.12.017 
Lehosmaa, K., Jyväsjärvi, J., Virtanen, R., Ilmonen, J., Saastamoinen, J., \& Muotka, T. (2017). Anthropogenic habitat disturbance induces a major biodiversity change in habitat specialist bryophytes of boreal springs. Biological Conservation, 215, 169-178. https://doi.org/10.1016/j.biocon.2017.09.010

Lindo, Z., \& Whiteley, J. A. (2011). Old trees contribute bio-available nitrogen through canopy bryophytes. Plant and Soil, 342(1), 141-148. https://doi.org/10.1007/s11104-010-0678-6

Lindo, Z., Nilsson, M.-C., \& Gundale, M. J. (2013). Bryophyte-cyanobacteria associations as regulators of the northern latitude carbon balance in response to global change. Global Change Biology, 19(7), 2022-2035. https://doi.org/10.1111/gcb.12175

Liu, C., Bu, Z.-J., Mallik, A., Rochefort, L., Hu, X.-F., \& Yu, Z. (2020). Resource competition and allelopathy in two peat mosses: Implication for niche differentiation. Plant and Soil, 446(1), 229-242. https://doi.org/10.1007/s11104-019-04350-0

Liu, H., Gale, S. W., Cheuk, M. L., \& Fischer, G. A. (2018). Conservation impacts of commercial cultivation of endangered and overharvested plants. Conservation Biology, 33(2), 288-299. https://doi.org/10.1111/cobi.13216

Ludwiczuk, A., \& Asakawa, Y. (2019). Bryophytes as a source of bioactive volatile terpenoids A review. Food and Chemical Toxicology, 132, 110649. https://doi.org/10.1016/j.fct.2019.110649

Ludwiczuk, A., \& Asakawa, Y. (2020). Terpenoids and aromatic compounds from bryophytes and their central nervous system activity. Current Organic Chemistry, 24(1), 113-128. https://doi.org/10.2174/1385272824666200120143558 
MacIvor, J. S., \& Lundholm, J. (2011). Insect species composition and diversity on intensive green roofs and adjacent level-ground habitats. Urban Ecosystems, 14(2), 225-241. https://doi.org/10.1007/s11252-010-0149-0

Mägdefrau, K. (1982). Life-forms of bryophytes. In A. J. E. Smith (Ed.), Bryophyte Ecology (pp. 45-58). Springer Netherlands. https://doi.org/10.1007/978-94-009-5891-3_2

Marcisz, K., Kołaczek, P., Gałka, M., Diaconu, A.-C., \& Lamentowicz, M. (2020). Exceptional hydrological stability of a Sphagnum-dominated peatland over the late Holocene. Quaternary Science Reviews, 231, 106180. https://doi.org/10.1016/j.quascirev.2020.106180

Markham, J., \& Fernández Otárola, M. (2021). Bryophyte and lichen biomass and nitrogen fixation in a high elevation cloud forest in Cerro de La Muerte, Costa Rica. Oecologia, 195(2), 489-497. https://doi.org/10.1007/s00442-020-04840-4

Martin, A. (2015). The magical world of moss gardening. Timber Press.

Meiners, S. J., Kong, C.-H., Ladwig, L. M., Pisula, N. L., \& Lang, K. A. (2012). Developing an ecological context for allelopathy. Plant Ecology, 213(8), 1221-1227. https://doi.org/10.1007/s11258-012-0078-5

Michel, P., Burritt, D. J., \& Lee, W. G. (2011). Bryophytes display allelopathic interactions with tree species in native forest ecosystems. Oikos, 120(8), 1272-1280. https://doi.org/10.1111/j.1600-0706.2010.19148.x

Michel, P., Payton, I. J., Lee, W. G., \& During, H. J. (2013). Impact of disturbance on aboveground water storage capacity of bryophytes in New Zealand indigenous tussock grassland ecosystems. New Zealand Journal of Ecology, 37(1), 114-126. 
Moola, F., \& Roth, R. (2018). Moving beyond colonial conservation models: Indigenous protected and conserved areas offer hope for biodiversity and advancing reconciliation in the Canadian boreal forest1. Environmental Reviews. https://doi.org/10.1139/er-2018$\underline{0091}$

Neven, L. G. (2000). Physiological responses of insects to heat. Postharvest Biology and Technology, 21(1), 103-111. https://doi.org/10.1016/S0925-5214(00)00169-1

Oberndorfer, E., Broomfield, T., Lundholm, J., \& Ljubicic, G. (2020). Inuit cultural practices increase local-scale biodiversity and create novel vegetation communities in Nunatsiavut (Labrador, Canada). Biodiversity and Conservation, 29(4), 1205-1240. https://doi.org/10.1007/s10531-020-01931-9

Oishi, Y. (2009). A survey method for evaluating drought-sensitive bryophytes in fragmented forests: A bryophyte life-form based approach. Biological Conservation, 142(12), 28542861. https://doi.org/10.1016/j.biocon.2009.04.011

Oishi, Y., \& Hiura, T. (2017). Bryophytes as bioindicators of the atmospheric environment in urban-forest landscapes. Landscape and Urban Planning, 167, 348-355. https://doi.org/10.1016/j.landurbplan.2017.07.010

Palozzi, J. E., \& Lindo, Z. (2017). Boreal peat properties link to plant functional traits of ecosystem engineers. Plant and Soil, 418(1-2), 277-292. https://doi.org/10.1007/s11104$\underline{017-3291-0}$

Patiño, J., \& Vanderpoorten, A. (2018). Bryophyte biogeography. Critical Reviews in Plant Sciences, 37(2-3), 175-209. https://doi.org/10.1080/07352689.2018.1482444 
Pérez-Méndez, N., Jordano, P., García, C., \& Valido, A. (2016). The signatures of Anthropocene defaunation: Cascading effects of the seed dispersal collapse. Scientific Reports, 6(1), 24820. https://doi.org/10.1038/srep24820

Pharo, E. J., \& Zartman, C. E. (2007). Bryophytes in a changing landscape: The hierarchical effects of habitat fragmentation on ecological and evolutionary processes. Biological Conservation, 135(3), 315-325. https://doi.org/10.1016/j.biocon.2006.10.016

Pires, M. M., O’Donnell, J. L., Burkle, L. A., Díaz-Castelazo, C., Hembry, D. H., Yeakel, J. D., Newman, E. A., Medeiros, L. P., Aguiar, M. A. M. de, \& Guimarães, P. R. (2020). The indirect paths to cascading effects of extinctions in mutualistic networks. Ecology, 101(7), e03080. https://doi.org/10.1002/ecy.3080

Porada, P., Lenton, T. M., Pohl, A., Weber, B., Mander, L., Donnadieu, Y., Beer, C., Pöschl, U., \& Kleidon, A. (2016). High potential for weathering and climate effects of non-vascular vegetation in the Late Ordovician. Nature Communications, 7(1), 12113. https://doi.org/10.1038/ncomms12113

Porada, P., Weber, B., Elbert, W., Pöschl, U., \& Kleidon, A. (2013). Estimating global carbon uptake by lichens and bryophytes with a process-based model. Biogeosciences, 10(11), 6989-7033. https://doi.org/10.5194/bg-10-6989-2013

Porada, P., Weber, B., Elbert, W., Pöschl, U., \& Kleidon, A. (2014). Estimating impacts of lichens and bryophytes on global biogeochemical cycles. Global Biogeochemical Cycles, 28(2), 71-85. https://doi.org/10.1002/2013GB004705 
Porada, P., Van Stan, J. T., \& Kleidon, A. (2018). Significant contribution of non-vascular vegetation to global rainfall interception. Nature Geoscience, 11(8), 563-567. https://doi.org/10.1038/s41561-018-0176-7

Posa, M. R. C., Wijedasa, L. S., \& Corlett, R. T. (2011). Biodiversity and conservation of tropical peat swamp forests. BioScience, 61(1), 49-57. https://doi.org/10.1525/bio.2011.61.1.10

Potter, C., Klooster, S., \& Genovese, V. (2012). Net primary production of terrestrial ecosystems from 2000 to 2009. Climatic Change, 115(2), 365-378. https://doi.org/10.1007/s10584$\underline{012-0460-2}$

Proctor, M. C. F. (2000). Mosses and alternative adaptation to life on land. The New Phytologist, 148(1), 1-3.

Pykälä, J. (2019). Habitat loss and deterioration explain the disappearance of populations of threatened vascular plants, bryophytes and lichens in a hemiboreal landscape. Global Ecology and Conservation, 18, e00610. https://doi.org/10.1016/j.gecco.2019.e00610

Ranius, T., Hämäläinen, A., Egnell, G., Olsson, B., Eklöf, K., Stendahl, J., Rudolphi, J., Sténs, A., \& Felton, A. (2018). The effects of logging residue extraction for energy on ecosystem services and biodiversity: A synthesis. Journal of Environmental Management, 209, 409-425. https://doi.org/10.1016/j.jenvman.2017.12.048

Razzaghmanesh, M., Beecham, S., \& Kazemi, F. (2014). Impact of green roofs on stormwater quality in a South Australian urban environment. Science of The Total Environment, 470471, 651-659. https://doi.org/10.1016/j.scitotenv.2013.10.047 
Razzaghmanesh, M., Beecham, S., \& Salemi, T. (2016). The role of green roofs in mitigating Urban Heat Island effects in the metropolitan area of Adelaide, South Australia. Urban Forestry \& Urban Greening, 15, 89-102. https://doi.org/10.1016/j.ufug.2015.11.013

Rehm, E. M., Thomas, M. K., Yelenik, S. G., Bouck, D. L., \& D’Antonio, C. M. (2019). Bryophyte abundance, composition and importance to woody plant recruitment in natural and restoration forests. Forest Ecology and Management, 444, 405-413. https://doi.org/10.1016/j.foreco.2019.04.055

Reside, A. E., Butt, N., \& Adams, V. M. (2018). Adapting systematic conservation planning for climate change. Biodiversity and Conservation, 27(1), 1-29. https://doi.org/10.1007/s10531-017-1442-5

Reyes-García, V., \& Benyei, P. (2019). Indigenous knowledge for conservation. Nature Sustainability, 2(8), 657-658. https://doi.org/10.1038/s41893-019-0341-z

Rimington, W. R., Pressel, S., Duckett, J. G., Field, K. J., Read, D. J., \& Bidartondo, M. I. (2018). Ancient plants with ancient fungi: Liverworts associate with early-diverging arbuscular mycorrhizal fungi. Proceedings of the Royal Society B: Biological Sciences, 285(1888), 20181600. https://doi.org/10.1098/rspb.2018.1600

Robinson, S. I., McLaughlin, Ó. B., Marteinsdóttir, B., \& O’Gorman, E. J. (2018). Soil temperature effects on the structure and diversity of plant and invertebrate communities in a natural warming experiment. Journal of Animal Ecology, 87(3), 634-646. https://doi.org/10.1111/1365-2656.12798

Roucoux, K. H., Lawson, I. T., Baker, T. R., Torres, D. D. C., Draper, F. C., Lähteenoja, O., Gilmore, M. P., Coronado, E. N. H., Kelly, T. J., Mitchard, E. T. A., \& Vriesendorp, C. 
F. (2017). Threats to intact tropical peatlands and opportunities for their conservation. Conservation Biology, 31(6), 1283-1292. https://doi.org/10.1111/cobi.12925

Rowe, D. B. (2011). Green roofs as a means of pollution abatement. Environmental Pollution, 159(8), 2100-2110. https://doi.org/10.1016/j.envpol.2010.10.029

Saarimaa, M., Aapala, K., Tuominen, S., Karhu, J., Parkkari, M., \& Tolvanen, A. (2019). Predicting hotspots for threatened plant species in boreal peatlands. Biodiversity and Conservation, 28(5), 1173-1204. https://doi.org/10.1007/s10531-019-01717-8

Schuster, R., Germain, R. R., Bennett, J. R., Reo, N. J., \& Arcese, P. (2019). Vertebrate biodiversity on indigenous-managed lands in Australia, Brazil, and Canada equals that in protected areas. Environmental Science \& Policy, 101, 1-6. https://doi.org/10.1016/j.envsci.2019.07.002

Schwartz, M. W. (2012). Using niche models with climate projections to inform conservation management decisions. Biological Conservation, 155, 149-156. https://doi.org/10.1016/j.biocon.2012.06.011

Seppelt, R. D., Downing, A. J., Deane-Coe, K. K., Zhang, Y., \& Zhang, J. (2016). Bryophytes within biological soil crusts. In B. Weber, B. Büdel, \& J. Belnap (Eds.), Biological Soil Crusts: An Organizing Principle in Drylands (pp. 101-120). Springer International Publishing. https://doi.org/10.1007/978-3-319-30214-0_6

Seto, K. C., Fragkias, M., Güneralp, B., \& Reilly, M. K. (2011). A meta-analysis of global urban land expansion. PLOS ONE, 6(8), e23777. https://doi.org/10.1371/journal.pone.0023777

Shi, X.-M., Song, L., Liu, W.-Y., Lu, H.-Z., Qi, J.-H., Li, S., Chen, X., Wu, J.-F., Liu, S., \& Wu, C.-S. (2017). Epiphytic bryophytes as bio-indicators of atmospheric nitrogen deposition 
in a subtropical montane cloud forest: Response patterns, mechanism, and critical load. Environmental Pollution, 229, 932-941. https://doi.org/10.1016/j.envpol.2017.07.077

Shochat, E., Lerman, S. B., Anderies, J. M., Warren, P. S., Faeth, S. H., \& Nilon, C. H. (2010). Invasion, competition, and biodiversity loss in urban ecosystems. BioScience, 60(3), 199208. https://doi.org/10.1525/bio.2010.60.3.6

Singh, J. S. (2002). The biodiversity crisis: A multifaceted review. Current Science, 82(6), 638647.

Solga, A., Burkhardt, J., Zechmeister, H. G., \& Frahm, J.P. (2005). Nitrogen content, 15N natural abundance and biomass of the two pleurocarpous mosses Pleurozium schreberi (Brid.) Mitt. and Scleropodium purum (Hedw.) Limpr. in relation to atmospheric nitrogen deposition. Environmental Pollution, 134(3), 465-473. https://doi.org/10.1016/j.envpol.2004.09.008

Sperle, T., \& Bruelheide, H. (2021). Climate change aggravates bog species extinctions in the Black Forest (Germany). Diversity and Distributions, 27(2), 282-295. https://doi.org/10.1111/ddi.13184

Spohn, M., \& Kuzyakov, Y. (2013). Phosphorus mineralization can be driven by microbial need for carbon. Soil Biology and Biochemistry, 61, 69-75. https://doi.org/10.1016/j.soilbio.2013.02.013

Sun, S.-Q., Liu, T., Wu, Y.H., Wang, G.X., Zhu, B., DeLuca, T. H., \& Wang, Y-Q. (2017). Ground bryophytes regulate net soil carbon efflux: Evidence from two subalpine ecosystems on the east edge of the Tibet Plateau. Plant and Soil, 417(1-2), 363-376. https://doi.org/10.1007/s11104-017-3264-3 
Susca, T., Gaffin, S. R., \& Dell'Osso, G. R. (2011). Positive effects of vegetation: Urban heat island and green roofs. Environmental Pollution, 159(8), 2119-2126. https://doi.org/10.1016/j.envpol.2011.03.007

Szücs, P., Pénzes-Kónya, E., \& Hofmann, T. (2017). The bryophyte flora of the village of Almásfüzitő, a former industrial settlement in NW-Hungary. Cryptogamie, Bryologie, 38(2), 153-170. https://doi.org/10.7872/cryb/v38.iss2.2017.153

Taillardat, P., Thompson, B. S., Garneau, M., Trottier, K., \& Friess, D. A. (2020). Climate change mitigation potential of wetlands and the cost-effectiveness of their restoration. Interface Focus. https://doi.org/10.1098/rsfs.2019.0129

Thom, D., \& Seidl, R. (2016). Natural disturbance impacts on ecosystem services and biodiversity in temperate and boreal forests. Biological Reviews, 91(3), 760-781. https://doi.org/10.1111/brv.12193

Trencher, G., Bai, X., Evans, J., McCormick, K., \& Yarime, M. (2014). University partnerships for co-designing and co-producing urban sustainability. Global Environmental Change, 28, 153-165. https://doi.org/10.1016/j.gloenvcha.2014.06.009

Turetsky, M. R. (2003). The role of bryophytes in carbon and nitrogen cycling. The Bryologist, 106(3), 395-409.

Turetsky, M. R., Bond-Lamberty, B., Euskirchen, E., Talbot, J., Frolking, S., McGuire, A. D., \& Tuittila, E.-S. (2012). The resilience and functional role of moss in boreal and arctic ecosystems. New Phytologist, 196(1), 49-67. https://doi.org/10.1111/j.1469$\underline{8137.2012 .04254 . x}$ 
Victor, J. E., \& Makwarela, L. E. (2011). South Africa's succulents under threat. Bradleya, 2011(29), 137-142. https://doi.org/10.25223/brad.n29.2011.a17

Vollár, M., Gyovai, A., Szücs, P., Zupkó, I., Marschall, M., Csupor-Löffler, B., Bérdi, P., Vecsernyés, A., Csorba, A., Liktor-Busa, E., Urbán, E., \& Csupor, D. (2018). Antiproliferative and antimicrobial activities of selected bryophytes. Molecules, 23(7), 1520. https://doi.org/10.3390/molecules23071520

Vrijheid, M., Martinez, D., Aguilera, I., Ballester, F., Basterrechea, M., Esplugues, A., Guxens, M., Larrañaga, M., Lertxundi, A., Mendez, M., Murcia, M., Marina, L. S., Villanueva, C. M., \& Sunyer, J. (2012). Socioeconomic status and exposure to multiple environmental pollutants during pregnancy: Evidence for environmental inequity? J Epidemiol Community Health, 66(2), 106-113. https://doi.org/10.1136/jech.2010.117408

Wagner, S., Bader, M. Y., \& Zotz, G. (2014). Physiological ecology of tropical bryophytes. In D. T. Hanson \& S. K. Rice (Eds.), Photosynthesis in bryophytes and early land plants (pp. 269-289). Springer Netherlands. https://doi.org/10.1007/978-94-007-6988-5_15

Whitehead, J., Wittemann, M., \& Cronberg, N. (2018). Allelopathy in bryophytes-A review. Lindbergia, 41(1). https://doi.org/10.25227/linbg.01097

Wittmer, I. K., Scheidegger, R., Bader, H.-P., Singer, H., \& Stamm, C. (2011). Loss rates of urban biocides can exceed those of agricultural pesticides. Science of The Total Environment, 409(5), 920-932. https://doi.org/10.1016/j.scitotenv.2010.11.031

Xiao, B., Hu, K., Ren, T., \& Li, B. (2016). Moss-dominated biological soil crusts significantly influence soil moisture and temperature regimes in semiarid ecosystems. Geoderma, 263, 35-46. https://doi.org/10.1016/j.geoderma.2015.09.012 
Xing, X., Xu, X., Zhang, X., Zhou, C., Song, M., Shao, B., \& Ouyang, H. (2010). Simulating net primary production of grasslands in northeastern Asia using MODIS data from 2000 to 2005. Journal of Geographical Sciences, 20(2), 193-204. https://doi.org/10.1007/s11442$\underline{010-0193-y}$

Xu, J., Morris, P. J., Liu, J., \& Holden, J. (2018). PEATMAP: Refining estimates of global peatland distribution based on a meta-analysis. CATENA, 160, 134-140. https://doi.org/10.1016/j.catena.2017.09.010

Yuan, X., Xue, N., \& Han, Z. (2021). A meta-analysis of heavy metals pollution in farmland and urban soils in China over the past 20 years. Journal of Environmental Sciences, 101, 217-226. https://doi.org/10.1016/j.jes.2020.08.013

Yule, C. M. (2010). Loss of biodiversity and ecosystem functioning in Indo-Malayan peat swamp forests. Biodiversity and Conservation, 19(2), 393-409. https://doi.org/10.1007/s10531-008-9510-5

Zanatta, F., Engler, R., Collart, F., Broennimann, O., Mateo, R. G., Papp, B., Muñoz, J., Baurain, D., Guisan, A., \& Vanderpoorten, A. (2020). Bryophytes are predicted to lag behind future climate change despite their high dispersal capacities. Nature Communications, 11(1), 5601. https://doi.org/10.1038/s41467-020-19410-8

Zaynab, M., Fatima, M., Abbas, S., Sharif, Y., Umair, M., Zafar, M. H., \& Bahadar, K. (2018). Role of secondary metabolites in plant defense against pathogens. Microbial Pathogenesis, 124, 198-202. https://doi.org/10.1016/j.micpath.2018.08.034

Zhang, Y., \& Guo, L.-D. (2007). Arbuscular mycorrhizal structure and fungi associated with mosses. Mycorrhiza, 17(4), 319-325. https://doi.org/10.1007/s00572-007-0107-8 
Zhong, Y., Jiang, M., \& Middleton, B. A. (2020). Effects of water level alteration on carbon cycling in peatlands. Ecosystem Health and Sustainability, 6(1), 1806113. https://doi.org/10.1080/20964129.2020.1806113 